\title{
LAND USE AND CATCHMENT SIZE/SCALE ON THE WATER QUALITY DETERIORATION OF KINTA RIVER, PERAK, MALAYSIA
}

\author{
Azyana Y., ${ }^{1}$ Nik Norulaini N.A ${ }^{2}$ and Nurul Jannah H. ${ }^{3}$ \\ ${ }^{1}$ School of Distance Educations, Universiti Sains Malaysia (USM), 11800 Minden, Penang, Malaysia. \\ yana_hyt@yahoo.com, \\ ${ }^{2}$ Division of Biological Sciences, School of Distance Educations, Universiti Sains Malaysia (USM), 11800 \\ Minden, Penang, Malaysia. norulain@usm.my, \\ ${ }^{3}$ School of Distance Educations, Universiti Sains Malaysia (USM), 11800 Minden, Penang, Malaysia. \\ jannah_hasnan@hotmail.com \\ *norulain@usm.my (corresponding author)
}

\begin{abstract}
GIS and statistical analysis tools were used to examine the impact of catchment size and land use predictors that have an influence on the Kinta River water quality. The percentage of five land use predictor variables specifically forest land, agricultural land, developed areas, water bodies and mine areas were extracted from the entire catchment and buffer zones with radii ranging from 200 to $1000 \mathrm{~m}$. Correlation and regression analysis were conducted on twelve water quality parameters at ten selected stations. Results suggest that, in most cases, the entire catchment landscape characteristics appear to have slightly greater influence on water quality rather than the specific sampling site of predetermined buffer radii. Developed land use becomes the best indicator to predict the degradation of water quality. While forested land, agricultural land, mining areas and water bodies do not contribute much to the river pollution.
\end{abstract}

\begin{abstract}
ABSTRAK GIS dan analisis alat statistik digunakan untuk mengkaji kesan saiz kawasan tadahan air dan penentu guna tanah yang mempunyai pengaruh yang lebih besar ke atas kemerosotan kualiti Sungai Kinta. Peratusan lima penentu guna tanah khususnya tanah hutan, tanah pertanian, tanah membangun/maju, badan air dan kawasan lombong telah diekstrak daripada tadahan keseluruhan dan zon penampan dengan jejari antara $200-1000 \mathrm{~m}$. Analisis korelasi dan regrasi telah dijalankan terhadap dua belas parameter kualiti air di sepuluh stesen terpilih. Keputusan menunjukkan bahawa, dalam kebanyakan kes, landskap keseluruhan tadahan muncul untuk mempunyai pengaruh yang sedikit lebih besar ke atas kualiti air dan bukannya tapak persampelan tertentu jejari penampan yang telah ditetapkan. Kawasan guna tanah yang membangun/maju menjadi penunjuk terbaik untuk meramalkan kemerosotan kualiti air. Manakala tanah hutan, tanah pertanian, kawasan perlombongan dan kawasan-kawasan badan air tidak banyak menyumbang kepada pencemaran sungai.
\end{abstract}

(Keywords: water quality, entire catchment, developed area, GIS)

\section{INTRODUCTION}

In recent years, results of many conducted research show that the watershed management and catchment scale have become important factors in determining the impact of human development on water quality. The relationship between land use and water quality and quantity is complex [1]. However, many studies around the world have also shown that land use has a strong impact on water quality [2-5]. Some researchers proved that there are significant correlation between water quality parameters and land use types [2- 4, 6-7]. Unfortunately, the results of the relationship between land use and water quality parameters are found not consistent due to different land use types are associated with different water pollution problems. Geographic information system (GIS) software and increasingly available land use data facilitate watershed analysis by linking indicators of landscape condition to water quality parameters [8].

The study area is located in the central-eastern section of Kinta District, in the state of Perak, Peninsular Malaysia. Kinta catchment is approximately $2565.45 \mathrm{~km}^{2}$. The main function of Kinta River is mainly for water supply. Kinta River has been selected by Perak Drainage and 
Irrigation Department (DID Perak) as a part of ' 1 State 1 River' since 2005. Currently, it is classified under average Class III of National Water Quality Standards for Malaysia (NWQS) with a water quality index (WQI) of 51.9 to 76.5 (polluted).

The objectives of the research are to determine the effect of different types of land use and catchment size on river water quality and identify the best land use predictor of water quality degradation.

\section{MATERIAL AND METHODS}

Water quality data were collected from ten selected sampling points labeled (PT 1 to PT 10) along Pari tributaries that are located on the upper region of Kinta catchment (Figure 1).

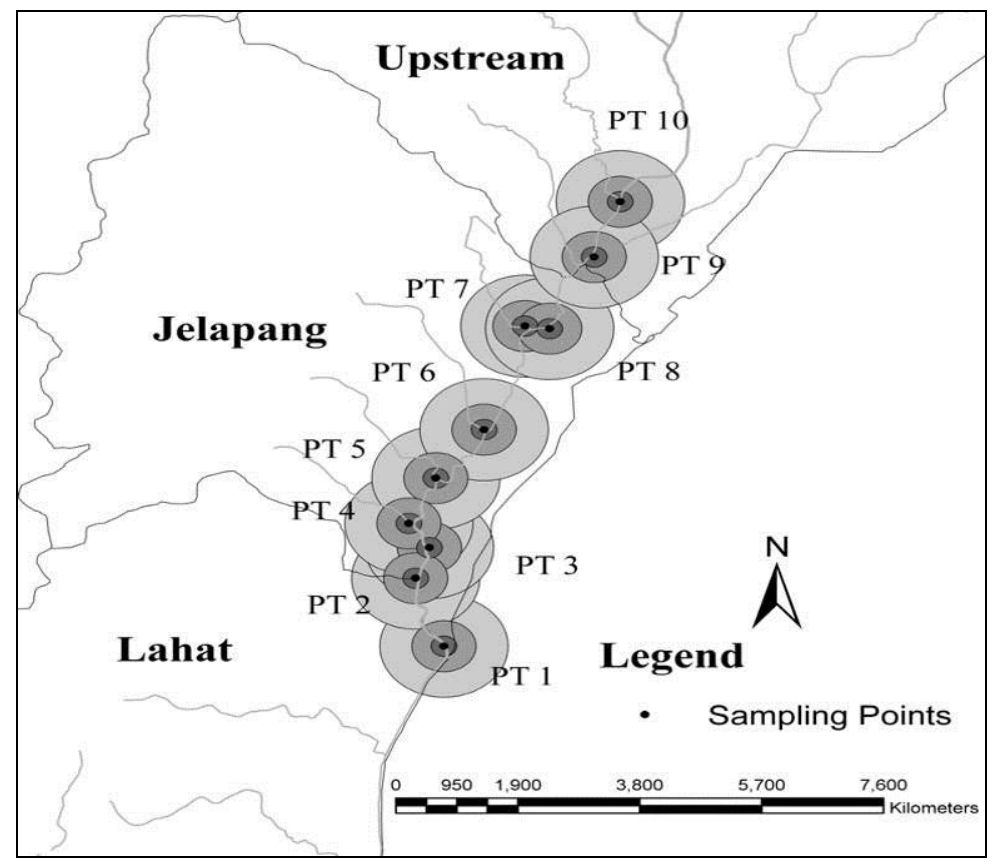

Figure 1: Locations of ten selected sampling points (PT 1 - PT 10) with buffer radii of 200 to $1000 \mathrm{~m}$ surrounding the sites

The selected sampling points and the surrounding land use within the predetermined circles of specific radii are assessed for possible interaction of land use and water quality. Water samples were taken for three consecutive days at three different time of day, early morning, afternoon and night. In-situ parameters vis temperature, dissolved oxygen (DO), conductivity, salinity, total dissolved solids (TDS) and $\mathrm{pH}$ were measured on the river water. Water sampled was then kept in a cool box and transported to a laboratory for analysis on chemical oxygen demand (COD), turbidity, nitrate, phosphate, biochemical oxygen demand (BOD) and suspended solids (SS). Arc View 9.3 Desktop Data Processing [9], a vector-based GIS software package, was used to determine the composition of the land use characteristics. The land use for each watershed was subdivided into five categories: 1) forest 2) agriculture 3) developed land 4) water body 5) mines. For each of the sub-watersheds, ArcView's buffer facility was used to extract land use data for the area within the $200 \mathrm{~m}, 500 \mathrm{~m}$ and $1000 \mathrm{~m}$ buffer radii of the catchment (Figure 1) that will allow a comparison of the influence of land use data on water quality. Multiple regressions [10] was used to determine whether land use factors exert positive or negative influence on water quality characteristics and the strength of this interaction by using five predictor variables. All the land use buffer radii; $200 \mathrm{~m}, 500 \mathrm{~m}$ and $1000 \mathrm{~m}$ are highly developed areas compared to other land use category except for PT 7. This watershed is made up of mainly forest land (54.98\%), only $18.02 \%$ developed areas and about $27 \%$ comprised of water bodies. Areas of other sampling points, PT 1 to PT 6 recorded no agricultural land or mining areas. 


\section{RESULTS AND DISCUSSION}

\section{Relationship between Forest land and Water Quality \\ Rivers located in the regions undisturbed by} human activities often have good water quality [11-12]. A significant positive relationship was observed between the percentage of forest land and DO concentrations for all sampling periods (morning, afternoon and night) especially at the entire catchment and within $500 \mathrm{~m}$ radius (Table
1). Higher DO values were observed in the upper catchments due to the natural turbulence in the river, which enhanced the mass transfer of oxygen between the river and atmosphere (natural re-aeration) [13]. This caused the occurrence of higher DO in the river waters. Other parameters such as conductivity, salinity, TDS, nitrate, phosphate and BOD showed a significant negative relationship of the entire catchment over the sampling period.

Table 1: Multiple regression results of forest land and water quality

\begin{tabular}{|c|c|c|c|c|}
\hline \multirow[b]{2}{*}{ Catchment Size } & \multirow[b]{2}{*}{ Parameter } & \multicolumn{3}{|c|}{ Sampling } \\
\hline & & Morning & Afternoon & Night \\
\hline \multirow[t]{10}{*}{ Entire catchment } & Temperature & & - & - \\
\hline & DO & + & + & + \\
\hline & Conductivity & - & - & - \\
\hline & Salinity & - & - & - \\
\hline & TDS & - & - & - \\
\hline & COD & - & - & \\
\hline & Nitrate & - & - & - \\
\hline & Phosphate & - & - & - \\
\hline & BOD & - & - & - \\
\hline & SS & - & + & \\
\hline \multirow[t]{4}{*}{$500 \mathrm{~m}$} & Temperature & & & - \\
\hline & DO & + & + & + \\
\hline & Conductivity & & & - \\
\hline & $\mathrm{pH}$ & & & - \\
\hline \multirow[t]{3}{*}{$1000 \mathrm{~m}$} & Temperature & & & - \\
\hline & DO & & + & + \\
\hline & $\mathrm{pH}$ & & & - \\
\hline
\end{tabular}

Forest cover within an area distinctly provides good water quality; the greater the forest cover, the better is the general water quality. Similar finding was found in different watersheds around the world [2-4]. The land use of areas closer to the sampling sites, such as within the $200 \mathrm{~m}$ radii do not show any significant impacts on the water quality. The positive effect of forest land can be offset if there are developments in adjacent areas. The relationship between extent of forest land and water quality parameters become weaker as the development increases.

\section{Relationship between Agricultural Land and Water Quality}

The presence of agricultural land within the regions surrounding the sampling points correlate negatively with almost all the parameters (Table 2). This is contrary to the 
Table 2: Multiple regression results of agricultural land and water quality

\begin{tabular}{|c|c|c|c|c|}
\hline \multirow[b]{2}{*}{ Catchment Size } & \multirow[b]{2}{*}{ Parameter } & \multicolumn{3}{|c|}{ Sampling } \\
\hline & & Morning & Afternoon & Night \\
\hline \multirow[t]{3}{*}{ Entire catchment } & DO & & + & \\
\hline & Salinity & - & & \\
\hline & SS & + & & \\
\hline \multirow[t]{7}{*}{$200 \mathrm{~m}$} & Temperature & + & & \\
\hline & Conductivity & & + & \\
\hline & Salinity & & + & \\
\hline & TDS & & + & \\
\hline & Salinity & & & + \\
\hline & Phosphate & & & + \\
\hline & BOD & & & + \\
\hline \multirow[t]{7}{*}{$500 \mathrm{~m}$} & Temperature & & & - \\
\hline & DO & + & + & + \\
\hline & Conductivity & - & - & - \\
\hline & Salinity & & & - \\
\hline & TDS & & - & - \\
\hline & $\mathrm{pH}$ & & & - \\
\hline & $\mathrm{COD}$ & & & - \\
\hline \multirow[t]{7}{*}{$1000 \mathrm{~m}$} & Temperature & & & - \\
\hline & DO & + & + & + \\
\hline & Conductivity & - & & - \\
\hline & Salinity & & & - \\
\hline & TDS & & & - \\
\hline & $\mathrm{pH}$ & & & - \\
\hline & COD & & & - \\
\hline
\end{tabular}

findings of many early studies in intensive agricultural areas [14-15] where they found that a rise in agricultural land has a strong positive correlation with parameters like conductivity and $\mathrm{pH}$. They suggested that the degradation in the water quality was closely related to the agriculture activities since these areas are nonpoint sources of pollution. DO concentrations seemed to have a significant positive relationship for almost any catchment size and sampling periods. In the study area, agriculture is not considered as critical source of pollution due to its sparse distribution. Agriculture is not an important pollution source within the study area, but it is still a good indicator to explain spatial variations in water quality [16]. The agricultural activities in the Kinta catchment are located at the upper regions (PT 9 and PT 10) and lower region (PT 1) as observed from the highest percentage of agricultural land typically oil palm plantations and rubber estates. Areas in other sampling points do not have agricultural activities. Watersheds with a lower percentage of agricultural land usually have a higher percentage of urban land that might be the primary pollution source, so significant negative relationships is seen between development and the lowering of water quality [16].

\section{Relationship between Developed Area and Water Quality}

Conductivity, salinity, TDS, nitrate, phosphate and BOD concentrations seemed to have a significant positive relationship with the entire catchment for all sampling periods (Table 3). 
Table 3: Multiple regression results of developed area and water quality

\begin{tabular}{|c|c|c|c|c|}
\hline \multirow[b]{2}{*}{ Catchment Size } & \multirow[b]{2}{*}{ Parameter } & \multicolumn{3}{|c|}{ Sampling } \\
\hline & & Morning & Afternoon & Night \\
\hline \multirow[t]{9}{*}{ Entire catchment } & Temperature & & + & + \\
\hline & DO & - & - & - \\
\hline & Conductivity & + & + & + \\
\hline & Salinity & + & + & + \\
\hline & TDS & + & + & + \\
\hline & COD & + & & \\
\hline & Nitrate & + & + & + \\
\hline & Phosphate & + & + & + \\
\hline & BOD & + & + & + \\
\hline $200 \mathrm{~m}$ & Nitrate & & & + \\
\hline \multirow[t]{4}{*}{$500 \mathrm{~m}$} & Temperature & & & + \\
\hline & DO & - & - & - \\
\hline & Conductivity & + & & \\
\hline & pH & + & & \\
\hline \multirow[t]{3}{*}{$1000 \mathrm{~m}$} & Temperature & & & + \\
\hline & DO & & - & - \\
\hline & pH & & & + \\
\hline
\end{tabular}

Significant negative effect was observed between DO and percentage of developed areas for all water sampled. Higher percentage of developed area will increase the concentrations of these parameters and decrease the DO level is and indicator of the degradation of river water quality. Urban land use/developed areas are the most important predictors of water quality variation similarly discovered by Osborne and Wiley 1988 [17]. They found that the urbanised area within the Salt Fork watershed is a major factor of soluble reactive phosphorous in the stream concentration rather than the agricultural area. PT 2 to PT 8 sampling points are located within the Jelapang watershed is the most developed area compared to Lahat and Upstream zones hence resulted in positive relationships. The rapid population growth, land development within the river basin, urbanisation and industrialisation have subjected the river to increase stress, giving rise to water pollution and environmental deterioration of the rivers [18]. Untreated or semi-treated wastewater from various industrial areas released to the nearest river such as from Jelapang Industrial Estate, caused the reduction in the water quality parameters indicating water pollution. For instance, the average readings of $\mathrm{DO}, \mathrm{COD}$, conductivity and TDS for all water sampled at PT 2 were $0.96 \mathrm{mg} / \mathrm{L}, 232 \mathrm{mg} / \mathrm{L}, 452 \mu \mathrm{S} / \mathrm{cm}$ and $226 \mathrm{mg} / \mathrm{L}$ respectively. Similar phenomenon occurred in Shanghai, China where higher urbanisation levels correspond to serious pollution [19]. Most of the rivers in the urban areas of the developing world are the end points of effluents discharged from the industries [20]. Insignificant relationships between land use predictor and some parameters indicate that the developed area is generally associated with lower concentration of water pollutants at some sampling points.

\section{Relationship between Water Body and Water Quality}

Conductivity, TDS, phosphate, and BOD show significant positive relationship within the entire catchment during all sampling periods. Water bodies act as recipient of pollutants where it absorbs all the pollutants that discharge from the nearest premises or any runoff pollutants from agricultural sectors. Even though water bodies recorded only in a small amount but it still acts 
Table 4: Multiple regression results of water body and water quality

\begin{tabular}{|c|c|c|c|c|}
\hline \multirow[b]{2}{*}{ Catchment Size } & \multirow[b]{2}{*}{ Parameter } & \multicolumn{3}{|c|}{ Sampling } \\
\hline & & Morning & Afternoon & Night \\
\hline \multirow[t]{9}{*}{ Entire catchment } & DO & - & - & - \\
\hline & Conductivity & + & + & + \\
\hline & Salinity & & + & + \\
\hline & TDS & + & + & + \\
\hline & COD & + & & \\
\hline & Turbidity & & & + \\
\hline & Nitrate & + & & + \\
\hline & Phosphate & + & + & + \\
\hline & BOD & + & + & + \\
\hline \multirow[t]{5}{*}{$200 \mathrm{~m}$} & Conductivity & & + & \\
\hline & Salinity & & + & \\
\hline & TDS & & + & \\
\hline & Nitrate & & & - \\
\hline & SS & & + & \\
\hline \multirow[t]{6}{*}{$500 \mathrm{~m}$} & Temperature & & & - \\
\hline & DO & + & + & + \\
\hline & Conductivity & - & & - \\
\hline & Salinity & & & - \\
\hline & TDS & - & & - \\
\hline & Nitrate & & & - \\
\hline \multirow[t]{2}{*}{$1000 \mathrm{~m}$} & Temperature & & & - \\
\hline & DO & + & + & \\
\hline
\end{tabular}

in an effective way as we can seen that most of the water quality parameters tested were recorded as significant positive relationship (Table 4). The DO concentrations decreased with the increase in percentage of water body especially at the entire catchment. This fact might be due to the water body that acts as a tool for reduction of nutrient content. Temperature is related to DO content. High temperature during daytime subsequently decreases in DO. Warmer waters do not hold DO as well as cooler waters hence gave negative relationship between temperature and water body at night. DO concentration is reduced when an increase in temperature occurs as oxygen saturation levels are temperature dependent [21].

\section{Relationship between Mining Area and Water Quality}

Mining land use as predictor is comprised of the quarry and ex-mining area. Both temperature and $\mathrm{pH}$ recorded as having negative relationship at the entire catchment and positive relationship within the more confined buffered zones (Table 5). Higher significant correlations exist when considering the entire catchment rather than smaller, limited regions within certain radius from a specific point of the river. A large percentage of mining areas are found at particularly around PT 1, PT 9 and PT 10. Acid mine drainage (AMD) and heavy metal were the greatest pollutant contributors of the mining operations even though the operations had ceased long time ago. The problem due to this 
Malaysian Journal of Science 31 (2): 121-131 (2012)

Table 5: Multiple regression results of mining area and water quality

\begin{tabular}{|c|c|c|c|c|}
\hline \multirow{2}{*}{ Catchment Size } & \multirow[b]{2}{*}{ Parameter } & \multicolumn{3}{|c|}{ Sampling } \\
\hline & & Morning & Afternoon & Night \\
\hline \multirow[t]{7}{*}{ Entire catchment } & Temperature & - & - & - \\
\hline & DO & + & + & + \\
\hline & Conductivity & - & - & - \\
\hline & Salinity & & & - \\
\hline & TDS & - & - & - \\
\hline & $\mathrm{pH}$ & & & - \\
\hline & $\mathrm{COD}$ & & & - \\
\hline \multirow[t]{4}{*}{$200 \mathrm{~m}$} & Temperature & + & & \\
\hline & Salinity & & & + \\
\hline & Phosphate & & & + \\
\hline & BOD & & & + \\
\hline \multirow[t]{4}{*}{$500 \mathrm{~m}$} & Temperature & + & & \\
\hline & Conductivity & & - & \\
\hline & TDS & & + & \\
\hline & $\mathrm{pH}$ & & & + \\
\hline $1000 \mathrm{~m}$ & Temperature & + & & \\
\hline
\end{tabular}

acidic wastewater can persist over many decades and go up to thousands of years [22]. Negative and positive relationships between the mining areas demonstrate that the $\mathrm{pH}$ might be low (acidic condition) or high (alkaline condition). It should be noted that not all mine water is characterized by low $\mathrm{pH}$ and it may contain elevated concentrations of metals at near neutral or alkaline $\mathrm{pH}$ values [22]. A significant positive relationship was also observed between percentage of mining area and DO concentration within the entire catchment during all sampling periods. DO concentrations increased as the percentage of mining areas increase probably due to the aeration/flowing of the water. Phosphate and BOD have a significant positive relationship within the buffer radius of $200 \mathrm{~m}$. Since these mining areas can act as nutrient recipients present in surface runoffs, the increase in phosphate and BOD level lead to eutrophication of the water body and the phenomenon can kill many fish and aquatic organisms, when DO is brought down markedly from the overgrowth of water plants.

\section{Relationship between Catchment Size and Water Quality}

The entire catchment site was the best catchment size due to the slightly greater influence on the water quality compared to buffer sampling sites radii from 200 to $1000 \mathrm{~m}$. Statistical analysis has shown that more number of significant relationships were observed within the entire catchment rather than isolated buffered radii areas. Taking selected areas with specific radius does not reflect high enough degree of influence of land use within the radius on the Kinta River water quality, especially with smaller radius of $200 \mathrm{~m}$. The quality of water sampled in the morning show variables having the highest multiple regression coefficients as conductivity $\left(R^{2}=0.76\right)$, salinity $\left(R^{2}=0.32\right)$, TDS $\left(R^{2}=0.55\right)$, COD $\left(R^{2}=0.27\right)$, turbidity $\left(R^{2}=0.09\right)$, nitrate $\left(R^{2}=0.35\right)$, phosphate $\left(R^{2}=0.95\right)$ and BOD $\left(R^{2}\right.$ $=0.52)$. These values are correlated with the entire catchment rather than selected zones of specific radii. Water sampled in the afternoon showed temperature, conductivity, TDS, $\mathrm{pH}$, COD, nitrate, phosphate, BOD and SS to be correlated with the entire catchment landscape predictors $\left(\mathrm{R}^{2}=0.37,0.65,0.65,0.13,0.23,0.2\right.$, $0.91,0.51$ and 0.28 , respectively) than specific buffered zones circumference. Night sampled water indicated conductivity, TDS, turbidity, nitrate, phosphate, BOD and SS as having the highest multiple regression coefficients $\left(\mathrm{R}^{2}=\right.$ 
$0.79,0.79,0.27,0.51,0.74,0.47$ and 0.08 , respectively) at the entire catchment compared to buffered zones. Table 6 shows the regression equations of the highest value of multiple regression coefficients $R^{2}$.

\section{Whole Catchment vs Buffer Catchment}

Watershed size is an important factor since land use and land cover influence the stream ecosystem [23]. Watershed management and catchment scale are important to determine the impact of human development on water quality. These studies become more common nowadays, but many questions still leave unanswered. For example, there is still an ongoing dispute regarding the catchment size/scale, which one has greater influence on the water quality $[2,17$, 24-25]. These uncertainties remain partly because each catchment has a unique combination of characteristics that influence water quality, and partly because thorough investigations at the watershed scale are extremely time and resource consuming [2]. Furthermore, watershed characteristics and the pollution sources are not same in different places [16]. Many researchers had studied the impacts of land use change in buffer zones within designated radius from the river on the river water quality and determined the functions of land use types in regulating the water quality by using the regression models [26-27]. However, our correlations and regression analysis results show that water quality is better correlated with the entire catchment scale landscape than buffer zone radii landscape. It was suggested that the land use pattern close to the river was not a better predictor of water quality than land use pattern at a distant from the river [28-29]. By increasing the buffer size, the land use pattern within the buffers more and more approaches the regional scale as suggested by Yin et al., 2005 [30]. The degradation of river water quality becomes clearer as the sources of pollution from all entire catchment concentrated at that point.

\section{CONCLUSION}

This study reveals that the physico-chemical characteristics of Kinta River water are highly correlated with the land use type both natural and anthropogenic activities. Correlation and regression techniques were used to evaluate the best catchment size. The analysis results indicate that the correlation of the water quality with the entire catchment scale landscape is slightly better than the correlation with the buffer zone radii landscape; which are $200 \mathrm{~m}, 500 \mathrm{~m}$ and $1000 \mathrm{~m}$. Furthermore, urban land use becomes the best indicator to predict the degradation of water quality. While forested land, agricultural land, mining areas and water body areas does not contribute much to the river pollution.

\section{REFERENCES}

1. Ngoye E. and Machiwa J. F. (2004). The influence of land-use patterns in the Ruvu river watershed on water quality in the river system. Physics and Chemistry of the Earth 29: 11611166.

2. Sliva L. and Williams D. D. (2001). Buffer zone versus whole catchment approaches to studying land use impact on river water quality. Water Research 35: 3462-3472.

3. Woli K. P., Nagumo T., Kuramochi K. and Hatano R. (2004). Evaluating river water quality through land use analysis and $\mathrm{N}$ budget approaches in livestock farming areas. Science of the Total Environment 329: 61-74.

4. Schoonover J. E., Lockaby B. G. and Pan S. (2005). Changes in chemical and physical properties of stream water across an urban-rural gradient in western Georgia. Urban Ecosystems 8: $107-124$.

5. Tu J., Xia Z. G., Clarke K. C. and Frei A. (2007). Impact of urban sprawl on water quality in eastern Massachusetts, USA. Environmental Management 40: 183-200.

6. Mehaffey M. H., Nash M. S., Wade T. G., Ebert D. W., Jones K. B. and Rager A. (2005). Linking land cover and water quality in New York City's water supply watersheds. Environmental Monitoring and Assessment 107: 29-44.

7. Stutter M. I., Langan S. J. and Demars B. O. L. (2007). River sediments provide a link between catchment pressures and ecological status in a mixed land use Scottish River system. Water Research 41: 2803-2815.

8. Kearns F. R., Kelly N. M., Carter J. L. and Resh V. H. (2005). A method for the use of landscape metrics in freshwater research and management. Landsc. Ecol. 20: 113-125. 
9. ESRI, ArcView User's Manual, Environmental Systems Research Institute, Redlands, California, 1996, pp. 1-349.

10. MathSoft, S-plus, Version 4.0 for Windows, MathSoft Inc., Seattle, WA. 1998, pp. 1-243.

11. Ometo J. P. H. B., Martinelli L. A., Ballester M. V., Gessner A., Krusche A. V., Victoria R. L. and Williams, M. (2000). Effects of land use on water chemistry and macroinvertebrates in two streams of the Piracicaba River basin, southeast Brazil. Freshwater Biol. 44: 327-337.

12. Swaine M. D., Adomako J., Ameka G., De Graft-Johnston K. A. A. and Cheek M. (2006). Forest river plants and water quality in Ghana. Aquat. Bot. 85: 299-308.

13. Lai Y. C., Yang C. P., Hsieh C. Y., Wu C. Y. and Kao C. M. (2011). Evaluation of non-point source pollution and river water quality using a multimedia two-model system. Journal of Hydrology 409: 583-595.

14. Tong S. T. Y. and Chen W. (2002). Modeling the Relationship Between Land Use and Surface Water Quality. Journal of Environmental Management 66:377-393.

15. Vondracek B., Blann K. L., Cox C. B., Nerbonne J. F. and Mumford K. G. (2005). Land Use, Spatial Scale, and Stream Systems: Lessons from an Agricultural Region. Environmental Management 36:775-791.

16. Tu J. (2011). Spatially varying relationships between land use and water quality across an urbanization gradient explored by geographically weighted regression. Applied Geography 31: 376-392.

17. Osborne L. L. and Wiley M. (1988). Empirical relationships between land use/cover and stream water quality in an agricultural watershed. Journal of Environmental Management 26: 9-27.

18. Sumok P. (2001). River water quality monitoring: sharing Sarawak experience. Proc. $6^{\text {th }}$ Sabah Inter-Agency Tropical Ecosystem (SITE) Research Seminar, Kota Kinabalu, Malaysia, September 13-14, pp. 4.

19. Wang M., Webber M., Finlayson B. and Barnett J. (2008). Rural industries and water pollution in China. Journal of Environmental Management 86: 648-659.

20. Phiri O., Mumba, P., Moyo B. H. Z. and Kadewa W. (2007). Assessment of the impact of industrial effluents on water quality of receiving rivers in urban areas of Malawi. Int. J. Environ. Sci. Technol. 2: 237-244.

21. Massoud M. A. (2011). Assessment of water quality along a recreational section of the Damour River in Lebanon using the water quality index. Environmental Monitoring and Assessment 18: 4151-4160.

22. Muhammad A. A., Mohd. J. M. and Ismail Y. (2012). Morphology, Geology and Water Quality Assessment of Former Tin Mining Catchment. The Scientific World Journal 1:1-15.

23. Strayer D. L., Beighley R. E., Thompson L. C., Brooks S., Nilsson C., Pinay G. and Naiman R. J. (2003). Effects of land cover on stream ecosystems: roles of empirical models and scaling issues. Ecosystems 6: 407-423.

24. Delong D. D. and Brusven M. A. (1991). Classification and spatial mapping of riparian habitat with application towards management of streams impacted by non point source pollution. Environ. Management 15: 565-571.

25. Johnson L. B., Richards C., Host G. E. and Arthur J. W. (1997). Landscape influences on water chemistry on Midwestern stream ecosystems. Freshwat. Biol. 37: 193-208.

26. Jarvie H. P., Oguchi T. and Neal C. (2002). Exploring the linkage between river water chemistry and watershed characteristics using GIS-based catchment and locality analyses. Regional Environment Change 3: 36-50.

27. Amiri B. J. And Nakane K. (2006). Modeling the relationship between land use and river water quality in the Yamaguchi Prefecture of Japan. Journal of Ecology and Field Biology 29: 343352.

28. Houlahan J. E. and Findlay C. S. (2004). Estimating the 'critical' distance at which adjacent land-use degrades wetland water and sediment quality. Landscape Ecology 19: 677690. 
29. Meynendonckx J., Heuvelmans G., Muys B. and Feyen J. (2006). Effects of watershed and riparian zone characteristics on nutrient concentrations in the River Scheldt Basin. Hydrology and Earth System Sciences 10: 913922.

30. Yin Z, Y., Walcott S., Kaplan B., Cao J., Lin W., Chen M., Liu D. and Ning Y. (2005). An analysis of the relationship between spatial patterns of water quality and urban development in Shanghai, China. Computers, Environment and Urban Systems 29: 197-221. 
Table 6: The regression equations of the highest value of multiple regression coefficients $\mathrm{R}^{2}$

\section{Morning}

Conductivity $=620$ - 5.2 Forest land + 0.2 Agricultural Land - 2.8 Developed Area + 13.5 Water Body - 87.3 Mining Area

Salinity $=0.28-0.0023$ Forest land - 0.0011 Agricultural Land - 0.0004 Developed Area - 0.0024 Water Body - 0.0110 Mining Area

TDS $=741$ - 7.18 Forest land - 6.02 Agricultural Land - 5.14 Developed Area - 3.1 Water Body - 18.6 Mining Area

$\mathrm{COD}=491-4.0$ Forest land - 5.0 Agricultural Land - 2.6 Developed Area - 0.9 Water Body + 20.5 Mining Area

Turbidity $=64-0.48$ Forest land - 0.65 Agricultural Land - 0.49 Developed Area +1.06 Water Body + 5.61 Mining Area

Nitrate $=4.0-0.037$ Forest land - 0.033 Agricultural Land - 0.026 Developed Area + 0.045 Water Body + 0.074 Mining Area

Phosphate $=-15.6+0.153$ Forest land + 0.189 Agricultural Land + 0.161 Developed Area + 0.496 Water Body - 0.347 Mining Area

$\mathrm{BOD}=-64+0.63$ Forest land +0.68 Agricultural Land +0.70 Developed Area +2.61 Water Body +2.99 Mining Area

\section{Afternoon}

Temperature = 46.9 - 0.168 Forest land - 0.119 Agricultural Land - 0.143 Developed Area - 0.198 Water Body - 1.13 Mining Area

Conductivity = 1543 - 14.1 Forest land - 8.6 Agricultural Land - 12.3 Developed Area + 0.1 Water Body - 102 Mining Area

TDS $=769$ - 7.04 Forest land - 4.28 Agricultural Land - 6.14 Developed Area + 0.07 Water Body - 50.6 Mining Area

$\mathrm{pH}=10.1-0.0309$ Forest land - 0.0231 Agricultural Land - 0.0307 Developed Area - 0.0483 Water Body - 0.238 Mining Area

$\mathrm{COD}=1607$ - 15.7 Forest land - 13.7 Agricultural Land - 14.0 Developed Area - 12.0 Water Body + 22.2 Mining Area

Nitrate $=3.34-0.0298$ Forest land - 0.0289 Agricultural Land - 0.0220 Developed Area - 0.0174 Water Body - 0.040 Mining Area

Phosphate $=-13.8+0.137$ Forest land +0.160 Agricultural Land + 0.145 Developed Area + 0.412 Water Body - 0.068 Mining Area

$\mathrm{BOD}=17.2$ - 0.173 Forest land - 0.230 Agricultural Land - 0.002 Developed Area - 0.032 Water Body + 1.91 Mining Area

SS = 283 - 2.65 Forest land - 2.88 Agricultural Land - 2.66 Developed Area - 3.36 Water Body - 0.61 Mining Area

\section{Night}

Conductivity = 1439 - 13.2 Forest land - 7.2 Agricultural Land - 11.0 Developed Area + 5.6 Water Body - 133 Mining Area

TDS $=716$ - 6.58 Forest land - 3.59 Agricultural Land - 5.47 Developed Area + 2.76 Water Body - 66.6 Mining Area

Turbidity = $206-1.97$ Forest land - 1.90 Agricultural Land - 1.90 Developed Area - 1.04 Water Body - 3.44 Mining Area

Nitrate $=-5.52+0.0580$ Forest land +0.0607 Agricultural Land +0.0665 Developed Area +0.0610 Water Body +0.0658 Mining Area

Phosphate $=-23.5+0.236$ Forest land +0.308 Agricultural Land + 0.255 Developed Area +0.471 Water Body -0.710 Mining Area

$\mathrm{BOD}=-25.6+0.281$ Forest land + 0.550 Agricultural Land + 0.311 Developed Area + 1.13 Water Body - 4.45 Mining Area

SS = $104-0.86$ Forest land - 0.87 Agricultural Land - 0.89 Developed Area - 1.09 Water Body - 2.58 Mining Area 